\title{
Evaluating macroinvertebrate biological metrics for ecological assessment of streams in northern Portugal
}

\author{
Simone G. Varandas • Rui Manuel Vitor Cortes
}

Received: 26 November 2008 / Accepted: 13 May 2009 / Published online: 2 June 2009

(C) Springer Science + Business Media B.V. 2009

\begin{abstract}
A procedure to select the most relevant metrics for assessing the ecological condition of the Douro basin (north Portugal) was developed based upon a set of 184 benthic community metrics. They were grouped into 16 biological categories selected from literature using data collected over 2 years from 54 sites along 31 rivers covering the whole perceived range of human disturbance. Multivariate analyses were carried out to identify the main trends in the macroinvertebrate data, to select reference versus impaired sites, to avoid multicolinearity between metrics, and to identify those that were clearly independent from natural stream typology. Structural metrics, adaptation metrics, and tolerance measures most effectively responded across a range of human influence. We find these attributes to be ecologically sound for monitoring Portugal's lotic ecosystems and providing information relevant to the Water Frame-
\end{abstract}

Electronic supplementary material The online version of this article (doi:10.1007/s10661-009-0996-4) contains supplementary material, which is available to authorized users.

S. G. Varandas $(\varangle) \cdot$ R. M. V. Cortes CITAB-Center for Research and Technology of Agro-Environment and Biological Sciences, Forestry Department, Universidade de Trás-os-Montes e Alto Douro, Apartado 1013, 5001-801, Vila Real, Portugal

e-mail: simonev@utad.pt work Directive, which asserts that the definition of water quality depends on its "ecological status", independent of the actual or potential uses of those waters.

Keywords Attributes - Traits • Benthic fauna • Ecological condition • Biomonitoring • Aquatic ecosystems

\section{Introduction}

Over the past century, increasing stress on ecosystems has resulted in persistent efforts to find a universal indicator capable of evaluating river quality to use as a tool able to detect impacts on biological resources. Important biological components have been measured and several indices have been developed in the light of these studies. However, none of the attributes used up until now contain a sufficient array of responses capable of distinguishing between different types of impacts (Dolédec et al. 1999). Freshwater biomonitoring has focused on changes in community structure and composition (distribution and abundance). Multimetric approaches integrate several descriptors of the sampled assemblage (Karr 1991; Niemi and McDonald 2004), which can synthesize and interpret large amounts of information and cover effects of multiple stressors (Bonada et al. 2006, 2007; Karr et al. 1986; Lillie et al. 2003). Barbour 
et al. (1995) and Davis et al. (1996) have also verified that, for a broad range of human impacts on aquatic ecosystems, combined multiple metrics provide an effective way of assessing water resources. Multimetric techniques have been criticized due to the loss of ecological information caused by aggregating metrics into a unique index value (Norris 1995; Suter 1993). Other techniques that rely on multivariate statistical analyses have also been worldwide developed (Wright 1995; Cortes et al. 1998; Oliveira and Cortes 2006; Peeters 2001). Multivariate approaches are based upon statistical relationships between fauna and selected environmental characteristics to discern patterns in community composition. Furthermore, the multivariate analyses provide a statistical objective method for grouping sites with similar macroinvertebrates communities (Reynoldson et al. 1997). Examples of complex but intensively used systems include the River Invertebrate Prediction and Classification System (Wright 1995) used in UK and its derivative, the Australian River Assessment Scheme models (Simpson and Norris 2000) used in Australia and Benthic Assessment of Sediment (Reynoldson et al. 1995) used in parts of Canada.

In recent years, there has been a return to basic ecology, using species traits and functional groups in ecological studies (e.g., Lenat 1993; Palmer et al. 1996; Poff and Allan 1995; Statzner et al. 1994, 1997; Pont et al. 2006; Tomanova et al. 2006). Besides recording species loss or reduction as a result of stress conditions, species traits can pinpoint life history characteristics, more sensitive to disturbance (Phillips 2004). As Poff (1997) states, "traits presumably represent functional relationships with important environmental selective forces, such as stream flooding or drying, local shear stress, temperature extremes, and human pollution”. Reinforcing this idea, Bonada et al. (2007) found that studies at larger spatial scales and higher biological organizational levels using biological traits can anticipate impacts of climate change.

Based upon these findings, a logical step forward would be to test, for the purpose of bioassessment alongside conventional metrics, new attributes (traits of reproduction, life cycle, growth, locomotion, dispersion, etc.) that repre- sent adaptive responses to environmental factors. This study aims to exploit the strengths of both multimetric and multivariate procedures for assessing the suitability of metrics in evaluating the ecological status of water courses. This integrated approach has been used by authors such as Zamora-Munoz and Alba-Tercedor (1996) and Cortes et al. (2002b) namely a multivariate approach to classify sites a priori and establish reference conditions based on environmental variables followed by a multimetric method, based upon a wide range of community characteristics, to then select core metrics by comparing community structure at reference sites and impaired sites.

A nationwide surface water quality monitoring is coordinated by the National Institute of Water (INAG). Until the implementation of Water Framework Directive (WFD; Directive 2000/60/CE-European Commission 2000), the national network consisted of 109 sampling sites, primarily in large rivers ( 24 river systems). The most important reservoirs whose main use is domestic water supply are included in the program as well. Water samples were taken at monthly intervals and analyzed only for general chemical and physical variables, organic pollution indicators, nutrients, and some heavy metals. The biomonitoring programs that have been carried out almost always are restricted to biological indexes developed for other countries such as Iberian Biological Monitoring Working Party (BMWP'; Alba-Tercedor 2000) and Belgian Biotic Index (BBI; De Pauw and Vanhooren 1983).

Nowadays, under WFD, Portugal is required to develop programs to evaluate physical, chemical, and biological integrity and to adopt water quality standards to restore and maintain that integrity. The WFD is the most important new European legislation concerning aquatic resource management to emerge for decades. The aim of the WFD is long-term sustainable water management based on a high level of protection of the aquatic environment (inland and coastal waters) and prevents further deterioration through better land management. Successful implementation of the WFD will go a long way to protecting and enhancing the quality of all stages of the water cycle in a sustainable manner. Current European Water Policy addresses the increasing awareness 
and participation of citizens, stakeholders, and other involved parties in decision making. The WFD is innovative since it asserts that the definition of water quality depends on its "ecological status" independent of the actual or potential uses of those waters. Ecological status derives from the assessment of surface water bodies, defined by the global expression of the structure and function of selected biological communities, taking into account geographical and climatic factors as well as the physical and chemical descriptors, including those resulting from human activities. This approach takes into consideration the overlapping unequal and dynamic influence of the three key components (physical, chemical, and biological integrity), similar to the pattern established after Yoder (1995; from Barbour and Yoder 2000). The proposed methodology aims to provide tools that contribute to the implementation of the WFD in defining monitoring programs.

\section{Materials and methods}

Study sites and sample collection

Data were collected from the Portuguese section of the Douro catchment and covered all the major tributaries (Fig. 1). The main river of this catchment (river Douro) flows generally westward across Spain and northern Portugal to the Atlantic Ocean at Foz do Douro. It has extensive large traffic in its Portuguese section and is fully regulated for hydropower purposes. Tributaries are small and flow into canyons to enter the larger river. The main impacts of the study area are the

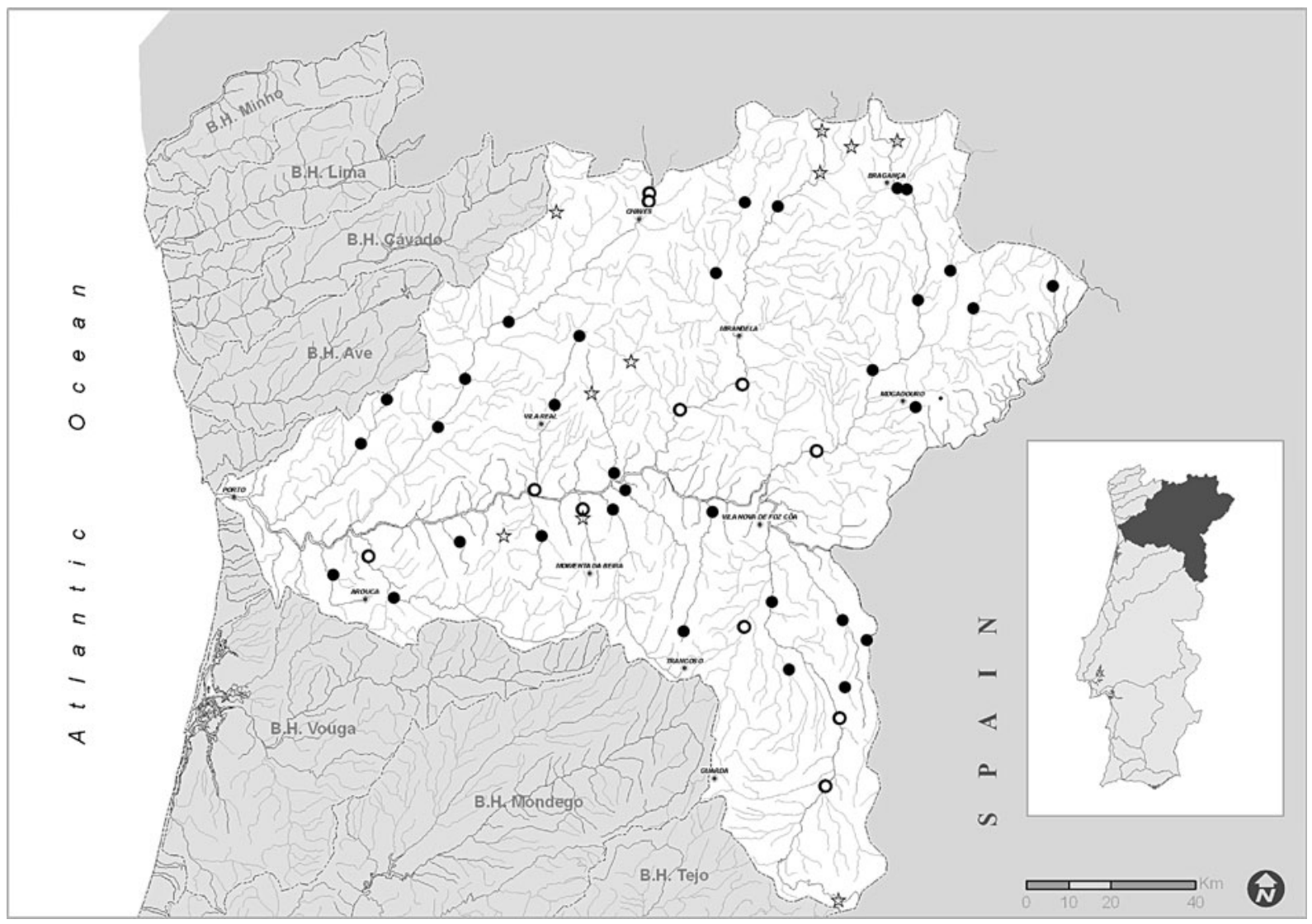

Fig. 1 Location of the Douro basin in north Portugal, showing sampled sites. Reference (star) and highly impaired sites (unfilled circle) are illustrated. The full circles are sites with fair impairment 
strong urban pressure in the coastal strip creating environmental problems with very negative effects in the running water. The remaining area is dominated by agroforestry and low population density. The main characteristics of reference and impacted sites are summarized in Table 1.

Benthic macroinvertebrates were sampled in summer 1997 and 2000 at 54 sites from 31 rivers

Table 1 Main characteristics of studied sites of the Douro basin (reference and impacted sites)

\begin{tabular}{|c|c|c|c|}
\hline & Method & $\begin{array}{l}\text { Reference sites } \\
\text { mean (min-max) }\end{array}$ & $\begin{array}{l}\text { Impaired sites } \\
\text { mean (min-max) }\end{array}$ \\
\hline Altitude (m) & $\begin{array}{l}\text { Measured from 1:25000 } \\
\text { topographic maps }\end{array}$ & $535(121-823)$ & $310(76-653)$ \\
\hline Mean catchment slope & Van Haveren (1986) method & $0.42(0.20-0.74)$ & $0.52(0.28-0.85)$ \\
\hline Stream order & $\begin{array}{l}\text { Strahler system measured in } \\
1: 250,000 \text { topographic maps }\end{array}$ & $3(2-4)$ & $4(3-6)$ \\
\hline $\begin{array}{l}\text { Mean wetted channel } \\
\text { width }(\mathrm{m})\end{array}$ & $\begin{array}{l}\text { Distance from bank to bank } \\
\text { at a transect representative } \\
\text { of the stream width in the } \\
\text { sampled area using a } \\
\text { tape measure }\end{array}$ & $6.6(2.6-14.6)$ & $20.2(6.8-80)$ \\
\hline Mean water depth (m) & $\begin{array}{l}\text { Measured at } 3 \text { transects over } \\
\text { the sampled reach using } \\
\text { a graduated stick }\end{array}$ & $0.45(0.17-0.60)$ & $0.74(0.35-1.45)$ \\
\hline $\begin{array}{l}\text { Distance from } \\
\text { source }(\mathrm{km})\end{array}$ & $\begin{array}{l}\text { Distance from source (headwater) } \\
\text { to the sampling site } \\
\text { measured along the river from } \\
\text { 1:250,000 topographic maps }\end{array}$ & $28(10-63)$ & $71(40-110)$ \\
\hline $\begin{array}{l}\text { Mean daily air } \\
\text { temperature }\left({ }^{\circ} \mathrm{C}\right)\end{array}$ & $\begin{array}{l}\text { Average air temperature } \\
\text { measured during the period } \\
\text { 1931-1960 from 1:1,000,000 } \\
\text { Atlas do Ambiente. It was } \\
\text { used the maximum value } \\
\text { of each class }\end{array}$ & $12.3(10-15)$ & $14.2(12-16)$ \\
\hline $\begin{array}{l}\text { Mean annual } \\
\text { precipitation }(\mathrm{mm})\end{array}$ & $\begin{array}{l}\text { Average annual precipitation } \\
\text { measured during the period } \\
\text { 1931-1960 from 1:1,000,000 } \\
\text { Atlas do Ambiente. It was } \\
\text { used class midpoint value }\end{array}$ & $1035(650-1300)$ & $745(550-1400)$ \\
\hline $\begin{array}{l}\text { Anthropogenic } \\
\text { perturbation-anthP }\end{array}$ & $\begin{array}{l}\text { Each perturbation factor in the } \\
\text { neighboring area to the reach } \\
\text { (e.g., agriculture, urban zone, } \\
\text { road beds, pasture, inert extraction, } \\
\text { parking lots, deforestation, } \\
\text { reforestation, waste, clear } \\
\text { cutting,...) received the weight } \\
\text { of } 1 \text { or } 2 \text { if it was present less or } \\
\text { more than } 10 \% \text {, respectively. } \\
\text { The final score was obtained by } \\
\text { the sum of all values of the } \\
\text { both slopes }\end{array}$ & $2.7(0-8)$ & $5.9(0-15)$ \\
\hline $\begin{array}{l}\text { Riparian canopy } \\
\text { cover-\%ripC }\end{array}$ & $\begin{array}{l}\text { Percentage of wetted bed shaded } \\
\text { by riparian vegetation, measured } \\
\text { with a spherical densiometer }\end{array}$ & $68(36-96)$ & $8(0-45)$ \\
\hline
\end{tabular}


Table 1 (continued)

\begin{tabular}{|c|c|c|c|}
\hline & Method & $\begin{array}{l}\text { Reference sites } \\
\text { mean (min-max) }\end{array}$ & $\begin{array}{l}\text { Impaired sites } \\
\text { mean (min-max) }\end{array}$ \\
\hline SAV & 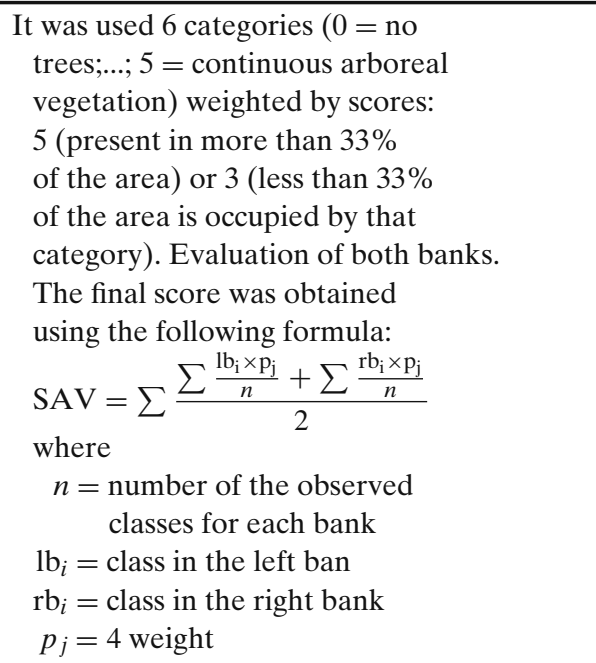 & $20.8(10-25)$ & $11.2(1.5-25)$ \\
\hline QBR & $\begin{array}{l}\text { Index developed by } \\
\text { Munné et al. (2003) }\end{array}$ & $85(60-100)$ & $60(20-90)$ \\
\hline UA & $\begin{array}{l}\text { Impact of urbanization on river. } \\
\begin{aligned} \text { Classes } 1 \text { to } 5: 1=\leq 1 \% \text { urban land; } \\
2=\text { low impact ( } \leq 10 \% \text { urban land }) ; \\
3=\text { moderate impact }(10-20 \% \text { urban land); } \\
4=\text { strong impact }(20-40 \% \text { urban land }) ; \\
5=\text { Severe impact ( } \geq 40 \% \text { urban land) }\end{aligned}\end{array}$ & $1(1-2)$ & $2(1-4)$ \\
\hline SLS & $\begin{array}{l}\text { Deviation from natural stream } \\
\text { bottom as a result of deposition. } \\
\text { Classes } 1 \text { to } 5 \text { with a score of } 5 \\
\text { representing maximum deviation } \\
\text { and } 1 \text { the minimum alteration }\end{array}$ & $1(1-2)$ & $2(2-3)$ \\
\hline $\begin{array}{l}\text { Affluent load generated } \\
\text { by human population } \\
(\mathrm{t} \text { year } \\
-1)\end{array}$ & $\begin{array}{l}\text { BOD_amount of biochemical } \\
\text { degradable substances (chemical } \\
\text { stressor) that flow into the stream; }\end{array}$ & $\begin{array}{l}45.4(7.5-139.3) \\
64.8(10.7-198.7) \\
9.1(1.5-27.8)\end{array}$ & $\begin{array}{l}750.7(86.7-1624) \\
1070.7(124-2315) \\
149.8(27.3-324.1)\end{array}$ \\
\hline $\begin{array}{l}\mathrm{BOD}_{5} \\
\mathrm{TSS} \\
N_{\text {tot }}\end{array}$ & $\begin{array}{l}\text { TSS - amount of sediments that } \\
\text { come into the stream and remain } \\
\text { in suspension in water column. }\end{array}$ & $2.8(0.5-8.5)$ & $45.8(5.3-98.9)$ \\
\hline$P_{\text {tot }}$ & $\begin{array}{l}N_{\text {tot }} \text { and } P_{\text {tot }} \text {-amount of total } \\
\text { nitrogen and total phosphorous } \\
\text { that comes into the stream, } \\
\text { respectively. Firstly was calculated } \\
\text { the generated load: total number } \\
\text { of inhabitants for drainage basin } \\
\text { multiplied by capitation-g/inhab } \\
\text { day (coefficient used in the Water } \\
\text { National Plan, 2001). Secondly, } \\
\text { the resulting value was multiplied } \\
\text { by } 1 \text { minus the proportion of removed } \\
\text { domestic load by treatment stations } \\
\text { of residual waters (the appropriate } \\
\text { conversion coefficients were used) }\end{array}$ & & \\
\hline Conductivity $\left(\mu \mathrm{S} \mathrm{cm}^{-1}\right)$ & Measured in the field using WTW LF 330 & $56(21-130)$ & $132(56-363)$ \\
\hline
\end{tabular}


distributed along the whole range of perceived environmental conditions. To assess anthropogenic impacts, attributes describing riparian vegetation, water quality, and instream variables were recorded at each site (some parameters are described in Tables 1 and 5). Composite multihabitat samples were taken at each site using a hand net $(350 \mu \mathrm{m}$ mesh size). Each habitat (e.g., riffle, pool, edge, vegetation) was sampled in proportion to its representation. Hand-net contents were store in sample containers and refrigerated, once in the laboratory macroinvertebrates were sorted live and preserved. All organisms were removed, counted, and identified using standard keys developed for the Iberian Peninsula, usually to species level of taxonomic resolution, with the exceptions of Hydracarina (order), Diptera (family, subfamily, or tribe for Chironomidae), Oligochaeta (family), and Coleoptera (genus or species).

\section{Identification of potential benthic metrics}

A total of 184 macroinvertebrate assemblage attributes were selected for testing as potential metrics. These attributes included 16 biological categories ("Electronic supplementary material") ranging from those traditionally tested and integrated in multimetric indices (richness, composition and dominance measures, tolerance and intolerance descriptors, and biotic indices) to species traits. A broader set of invertebrate traits were studied (respiration, resistance forms, locomotion, and substrate relation-habit/ behavior, habitat preference, forms to avoid the drift, functional feeding groups, life cycle characteristics, aquatic stages, reproduction metrics, dispersal measures, and maximal size) since that can be applied to larger temporal and spatial scales which may vary widely between ecoregions (Charvet et al. 2000; Statzner et al. 2005; Bonada et al. 2006). Selected metrics were compiled from a wide variety of works including Kerans and Karr (1994), Resh (1994), Statzner et al. (1994), Barbour et al. (1995, 1996, 1999), Fore et al. (1996), and Kashian and Burton (2000). Benthic macroinvertebrate traits were based on Charvet et al. (2000), Dolédec et al. (1999), and Usseglio-Polatera et al. (2000).
Functional feeding groups and habit/behavior were assigned according to the primary category documented by Tachet et al. (2002) and data bases supplied by "Usseglio-Polatera in 2005" and complemented with information based upon Merritt and Cummins (1996) and Barbour et al. (1999). Categorization according to sensitivity to pollution was based upon Alba-Tercedor and Sanchez-Ortega (1988), Cortes (1992), and Monzón (1996). Three biological indices were applied: the BMWP', BBI, and Family-Level Biotic Index (FBI; adapted from Hilsenhoff 1988). Family tolerance scores for the FBI index were used in agreement with Alba-Tercedor (2000), since they are adapted for the Iberian fauna. Reproduction metrics, resistance forms, mechanisms to avoid drift, dispersal measures, and maximal size were divided into classes (see "Electronic supplementary material") and calculated based on information described mainly in the last update of data bases supplied by "Usseglio-Polatera in 2005". Respiratory physiology and habitat preference macroinvertebrate classifications were based upon Hynes (1979), Richoux (1982), Margalef (1983), Faessel (1985), Askew (1988), Chinery (1992), Wetzel (1993), Fitter and Manuel (1994), Nieser et al. (1994), and Vieira-Lanero (2000). Other publications such as Thorp and Covich (1991) and online papers found via online literature searches were used to complement existing data or provide missing data. When conflicting natural history information for the same taxon occurred, we considered both sources of information. So, the two more important designations (except for life cycle duration that was considered the maximum of three designations) were used. Data were divided by the total number of designations.

All the above information used for assemblage characterization was supplemented and in some cases modified by specific information relating to local fauna and information found in literature and online sites. When ambiguities concerning a particular attribute could not be resolved, data were discarded. Whenever possible, metrics were defined at species level. Some of them included higher taxonomic levels (see "Electronic supplementary material"). Metrics were expressed in quantitative terms, most of them either as relative proportions or number of taxa. 
Data analysis

\section{Identification of reference and impaired sites}

Definition of human disturbance categories Disturbed and reference (or minimally disturbed) sites were identified, firstly, based on a criterion to assess the human impact of European rivers (FAME Consortium 2004) linked to the implementation of the WFD and in the principles of REFCOND (2003) and, secondly, by their physicochemical characteristics, for a consistent and independent split. By using the first criterion, sites were classified according to anthropogenic disturbance by quantifying ten stressors that covered from local impacts (observed in situ) to the ones at the catchment level determined from geographical information system, to assess impacts in the river basin upstream. The list of descriptors included land use intensification, urban area, structure of riparian layer (including invasive plants), river connectivity, sediment load, hydrological modifications (water abstraction and flow regulation), symptoms of acidification or toxicity, morphological condition, symptoms of eutrophication, and invasive plant or animal species. Each variable was allocated to one of five classes according to the magnitude of the stressor under evaluation $(1$ corresponds to high status $=$ reference conditions: only minor, negligible alterations, and 5 indicates a bad status: severe impact). This procedure allowed to define the reference sites (a) according to their total score, derived from ranking the scores of environmental degradation, and (b) when none of the above variables occurred in the two "worst" classes.

Finally, collected physical and chemical data were compared with the national Water Institute (INAG) water quality classification scheme which uses 27 parameters that describe principal nutrients and micropollutants, to classify water quality according to uses. Thus, a site was considered unimpaired if it belonged to class $\mathrm{A}$, impaired if it belonged to classes $\mathrm{B}$ or $\mathrm{C}$ and highly impaired if it belonged to classes D or E.

Species ordination The relation of the macroinvertebrate communities with the previous classi- fication of sites produced by the environmental variables was assessed by multivariate ordinations of species of taxa abundance structure (log $(x+1)$ transformed) for each year, using nonmetric multidimensional scaling analysis (NMDS) based on similarity scores (Bray-Curtis coefficient) using PRIMER v 5.2.2 (Clarke and Gorley 2001). Separation of reference and the most degraded sites was further refined by integrating the 1997 and 2000 data and checking for interannual variability. Reference sites with interannual consistency along disturbance categories were retained. A similarity percentages (SIMPER) analyses (SIMPER-species contributions) was done to quantify the degree of differences found between years or quality categories, as well as species that contribute more to these differences. This analysis although not perform formal test of hypotheses provides a list of species in order of their percentage contribution to dissimilarities (BrayCurtis dissimilarity) between groups or similarities within groups (Clarke and Warwick 2001). Metrics-derived values were then compared between reference and impaired sites defined above.

\section{Evaluation of metrics}

Biological patterns and human disturbance The optimal combination of potential metrics for discriminating between reference and degraded sites was determined using detrended correspondence analysis (DCA; Hill and Gauch 1980). This analysis evaluates the ecological sensitivity and response direction of all potential benthic attributes to increasing human stress for each year, extracting the most relevant biological patterns, and then relating them to patterns induced by human activity. DCA provides a more precise representation of environmental gradients than principal component analysis, since it arranges the data in such a way to avoid the compression of the ordination axes and quadratic distortion (Hill 1979). The data were $\log (x+1)$ transformed with the exception of metrics expressed in percentage. These metrics were not transformed since they were normally distributed (Shapiro-Wilk test for normality).

Assessment of metrics Pearson correlation coefficients of the DCA axis that best reflected the 
disturbance gradient and test metrics were derived; only significant correlations $(p \leq 0.05)$ were retained. The positive or negative signs of the Pearson correlation coefficients indicated the direction of the candidate metric (i.e., increasing or decreasing in response to perturbation). When signals of the two coefficients (year 1997 and year 2000) were not coincident, the response was considered as variable and eliminated, unless we knew the cause of variation. The DCA was computed using the package CANOCO version 4.0 (Ter Braak and Smilauer 1998). Metrics responses that were not in accordance with literature were also discarded.

Candidate metrics were further tested for ecological consistency. First, a coefficient of variation (CV) was calculated for each metric in the group of all reference sites that presented interannual consistency, as a measure of within-site variability. CVs were calculated from the multiyear reference data, once this combination had absorbed the interannual variability verified previously. Low $\mathrm{CV}$ is an important condition for determining the suitability of a metric in detecting anthropogenic impacts. Kashian and Burton (2000) state that CVs $>50 \%$ are ineffective in detecting between impaired and unimpaired conditions. Based on this criterion, only candidate metrics with CVs $<50 \%$ were retained for further analyses.

Based on the approach advocated by Barbour et al. (1996), metrics with many zero or low values in the reference sites were assessed to avoid nondetection of lower values. Metrics that followed this pattern were also eliminated from the subsequent tests ("Electronic supplementary material").

Obtaining a subset of independent metrics A preliminary canonical correspondence analysis (CCA) with forward selection (stepwise procedure) was performed, for both datasets (metrics and taxa abundance) containing the 2 years of samplings (1997 and 2000 combined), to eliminate metrics that did not make any significant contribution to explaining biological variation derived from disturbance. Only metrics with $p \leq$ 0.05 were selected for the next step. In order to distinguish between natural typological variability from perturbation-induced changes, typological variables such as distance from source, stream width, altitude, stream order, zonation (according to Illies and Botosaneanu 1963), catchment area upstream of the site, and total stream length were considered as covariables in this CCA. The resulting variation inflation factors (VIFs) were assessed. Metrics with high VIFs (>20) values imply redundancy (multicolinearity) with other metrics, a phenomenon that should be avoided since no unique contribution is made to the regression equation (Ter Braak and Smilauer 1998). Consequently, the metric with the highest VIF was excluded and the CCA procedure was repeated until all metrics exhibiting multicolinearity were excluded. The environmental and biological variables (metrics) were previously standardized $[(x-\bar{x}) \div \mathrm{sd}(x)]$ to achieve comparable scales and the macroinvertebrates abundance were transformed by $\log (x+1)$. The package CANOCO version 4.0 was used for the CCA analyses.

Establishing the relationship between metrics and human disturbance gradient Following the metrics selection procedure using CCA, Pearson correlations were derived between variables describing human disturbance and the preselected metrics, ensuring that only metrics that were good indicators of human impacts were retained. Variables used to test metrics were conductivity (cond), riparian canopy cover (\%ripC), anthropogenic perturbation (anthP), structure of arboreal vegetation (SAV), riparian habitat quality (QBR index; Munné et al. 2003), urbanization area (UA; categories 1-5), sediment load segment (SLS; categories $1-5)$, dissolved oxygen $\left(\mathrm{O}_{2}\right)$, turbidity, upstream dams (UD; categories 1-5), and effluent load generated by human population: biochemical oxygen demand $\left(\mathrm{BOD}_{5}\right)$, total suspended solids (TSS), total nitrogen $\left(N_{\text {tot }}\right)$, and total phosphorous $\left(P_{\text {tot }}\right)$. These variables and another ones (water temperature, substratum size, mean water depth and velocity, stream width, and stream flow) were measured simultaneously with invertebrates sampling. Finally, benthic attributes that best discriminated between the reference and degraded sites were illustrated by box-andwhisker plots. This method, described by Barbour 
et al. (1996), rejects metrics if the interquartile range of impaired or reference sites overlaps with the median of the other. Results from the 2 years were compared and only metrics that detected a gradient of human impact in both years were accepted as core metrics with potential to be part of a biological indicator system.

\section{Results}

Selection of reference and impaired sites

NMDS based on species/site data of 1997 (2D stress value $=0.23,3 \mathrm{D}$ stress value 0.17 ) and

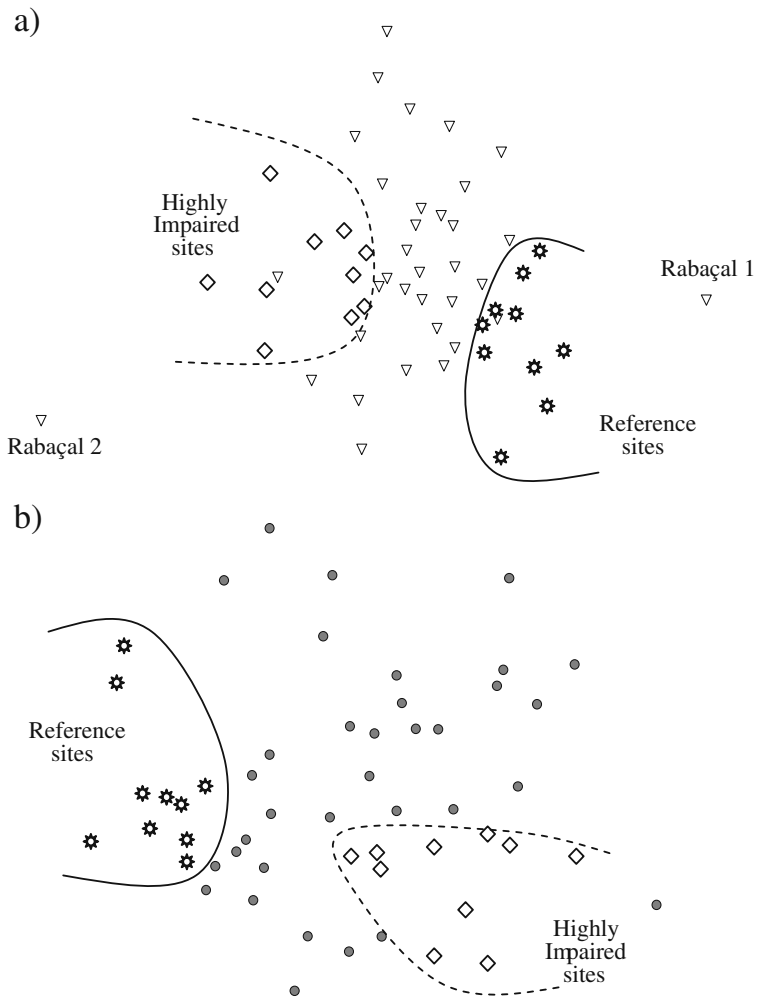

Fig. 2 NMDS ordination plot of sites a sampled in 1997. Outliers Rabaçal 1 and Rabaçal 2 were excluded from the impaired and reference sites, respectively, because they had low abundance and diversity probably caused by sampling difficulties. b Sampled in 2000. The curved lines represent an imaginary separation between the reference and impaired sites from the remaining ones. Identical symbols for reference and impaired sites were used to illustrate the same places

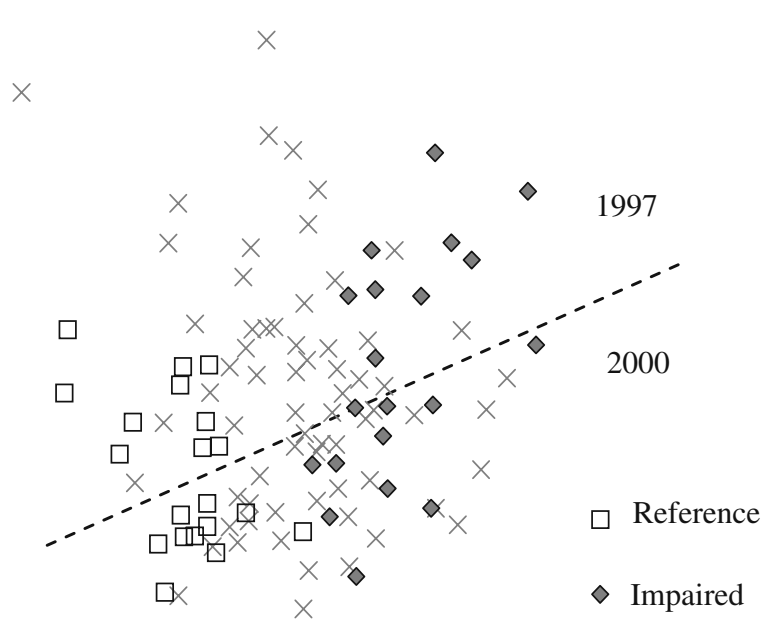

Fig. 3 NMDS ordination plot of multiyear data representing the variability between years and the separation between reference and impaired sites. The dot line represents an imaginary separation among years 1997/2000

data from 2000 (2D stress value $=0.19,3 \mathrm{D}$ stress value $=0.13)$ differentiated between undisturbed and highly impaired sites (Fig. 2a, b). That is, identified sites in the reference and highly impaired groups (ten sites in each category) for each year were basically the same (Fig. 2). The distinction between these two subsets of sites was confirmed with SIMPER tests performed in the multiyear NMDS ordination. NMDS analysis displayed a gradient of disturbance with the sites distributed along a gradient of human impacts of increasing magnitude. Average dissimilarity between 1997 and 2000 was $77.09 \%$, making clear the existence of a strong interannual variability (Fig. 3; Table 2). A total of 174 species ( $43 \%$ of the total taxa)

Table 2 Percentage breakdown of average dissimilarity between groups of years (1997 against 2000) and groups of impaired versus reference sites in Douro catchment, using SIMPER analysis

\begin{tabular}{llll}
\hline Factors & Groups & $\begin{array}{l}\text { Average } \\
\text { similarity (\%) }\end{array}$ & $\begin{array}{l}\text { Average } \\
\text { dissimilarity (\%) }\end{array}$ \\
\hline Years & 1997 & 25.07 & 77.09 \\
& 2000 & 33.30 & \\
Ref/Imp & Reference & 34.24 & 79.89 \\
& Impaired & 29.43 & \\
\hline
\end{tabular}


Table 3 Average contribution of species principally responsible for intragroup similarities within each year of sampling

\begin{tabular}{|c|c|c|c|}
\hline \multicolumn{2}{|l|}{1997} & \multicolumn{2}{|l|}{2000} \\
\hline Species & Contribution (\%) & Species & Contribution (\%) \\
\hline Chironomini gen. sp. & 14.81 & Chironomini gen. sp. & 11.11 \\
\hline Hydracarina & 11.55 & Caenis luctuosa & 7.99 \\
\hline Tanytarsini gen. sp. & 7.46 & Tanytarsini gen. sp. & 7.91 \\
\hline Tanypodinae gen. sp. & 6.96 & Tanypodinae gen. sp. & 6.59 \\
\hline Orthocladiinae gen. sp. & 5.33 & Hydracarina & 5.49 \\
\hline Caenis luctuosa & 4.49 & Orthocladiinae gen. sp. & 5.44 \\
\hline Lumbriculidae gen. sp. & 3.50 & Diptera pupae & 3.43 \\
\hline Dryops sp. & 2.71 & Aquarius najas & 3.32 \\
\hline Physella acuta & 2.17 & Hydropsyche sp. 2 & 2.60 \\
\hline Mystacides azurea & 1.97 & Simuliidae gen. sp. & 2.42 \\
\hline Calamoceras marsupus & 1.80 & Lumbriculidae gen. sp. & 2.15 \\
\hline Oulimnius sp. & 1.79 & Baetis fuscatus & 1.77 \\
\hline Laccophilus sp. & 1.67 & Mystacides azurea & 1.72 \\
\hline Diptera pupae & 1.66 & Gerridae juvenil & 1.64 \\
\hline Gomphus pulchelus & 1.59 & Ecdyonurus gr. venosus & 1.53 \\
\hline Lumbricidae gen. sp. & 1.54 & Leuctra aurita & 1.41 \\
\hline Aquarius najas & 1.32 & Choroterpes picteti & 1.32 \\
\hline Gerris sp. 1 & 1.23 & Ancylus fluviatilis & 1.23 \\
\hline Tubificidae gen. sp. & 1.18 & Laccophilus sp. & 1.22 \\
\hline Hydropsyche sp. 2 & 1.11 & Cloeon gr.simile & 1.21 \\
\hline Atyaephyra desmaresti & 1.09 & Baetis rhodani & 1.13 \\
\hline Platycnemis latipes/acutipennis & 1.07 & Hydroptilidae gen. sp. & 1.12 \\
\hline Leuctra fusca & 1.02 & Oulimnius sp. & 1.10 \\
\hline Boyeria irene & 0.95 & Cloeon gr. dipterum & 1.01 \\
\hline Euleuctra geniculata & 0.78 & Ephemerella ignita & 0.94 \\
\hline Atrichops sp. & 0.77 & Baetis sp. & 0.88 \\
\hline Baetis rhodani & 0.69 & Habrophlebia eldae & 0.86 \\
\hline Onychogomphus uncatus & 0.68 & Boyeria irene & 0.81 \\
\hline Erpobdella monostriata & 0.60 & Rhyacophila sp. & 0.77 \\
\hline Coenagrion puella & 0.57 & Polycentropus flavomaculatus & 0.75 \\
\hline Calopteryx virgo & 0.54 & Naucoris maculatus maculatus & 0.73 \\
\hline Stenelmis canaliculata & 0.53 & Leuctra geniculata & 0.72 \\
\hline Ecdyonurus gr.venosus & 0.49 & Hydrometra stagnorum & 0.72 \\
\hline Corixidae gen. sp. & 0.49 & Enchytraeidae gen. sp. & 0.72 \\
\hline Atherix sp. & 0.47 & Erpobdella monostriata & 0.64 \\
\hline Anacaena sp. & 0.46 & Gerris lateralis & 0.61 \\
\hline Simuliidae gen. sp. & 0.42 & Physa fontinalis & 0.61 \\
\hline Leuctra sp. 1 & 0.42 & Micronecta scholtzi & 0.55 \\
\hline Haliplus sp. & 0.42 & Calamoceras marsupus & 0.52 \\
\hline Naucoris maculatus maculatus & 0.42 & Platycnemis latipes/acutipennis & 0.50 \\
\hline Hydrochus sp. & 0.40 & Onycogomphus uncatus & 0.47 \\
\hline Nepa cinerea & 0.39 & Tubificidae gen. sp. & 0.46 \\
\hline Platycnemis cf. latipes & 0.35 & Pseudocentroptilum pennulatum & 0.42 \\
\hline Potamopyrgus jenkinsi & 0.34 & Leuctra sp. 1 & 0.41 \\
\hline & & Epeorus silvicola & 0.39 \\
\hline & & Dryops sp. & 0.37 \\
\hline & & Allogamus ligonifer & 0.31 \\
\hline & & Pyrrhosoma nymphula & 0.31 \\
\hline
\end{tabular}


Table 4 Average contribution of species principally responsible for intragroup similarities within reference and highly impaired sites

\begin{tabular}{|c|c|c|c|c|c|}
\hline \multicolumn{3}{|l|}{ Reference } & \multicolumn{3}{|l|}{ Impaired } \\
\hline Species & $\begin{array}{l}\text { Contribution } \\
(\%)\end{array}$ & $\begin{array}{l}\text { Abundance } \\
\text { class }\end{array}$ & Species & $\begin{array}{l}\text { Contribution } \\
(\%)\end{array}$ & $\begin{array}{l}\text { Abundance } \\
\text { class }\end{array}$ \\
\hline Chironomini gen. sp. & 6.66 & - & Chironomini gen. sp. & 18.94 & + \\
\hline Hydracarina & 6.59 & - & Caenis luctuosa & 15.76 & + \\
\hline Tanytarsini gen. sp. & 5.63 & - & Hydracarina & 12.38 & + \\
\hline Orthocladiinae gen. sp. & 4.93 & - & Tanypodinae gen. sp. & 6.68 & + \\
\hline Tanypodinae gen. sp. & 4.37 & - & Orthocladiinae gen. sp. & 5.87 & + \\
\hline Calamoceras marsupus & 3.77 & + & Tanytarsini gen. sp. & 5.84 & + \\
\hline Oulimnius sp. & 2.99 & + & Atyaephyra desmaresti & 4.46 & + \\
\hline Habrophlebia eldae & 2.88 & + & Diptera pupae & 2.98 & + \\
\hline Aquarius najas & 2.81 & + & Lumbriculidae gen. sp. & 2.91 & + \\
\hline Leuctra sp. 1 & 2.78 & + & Physella acuta & 1.69 & + \\
\hline Ecdyonurus gr. venosus & 2.48 & + & Aquarius najas & 1.45 & - \\
\hline Polycentropus sp. 1 & 2.45 & + & Hydropsyche sp. 3 & 1.36 & + \\
\hline Dryops sp. & 2.36 & - & Coenagrion puella & 1.34 & + \\
\hline Onycogomphus uncatus & 2.36 & + & Mystacides azurea & 1.17 & + \\
\hline Atherix sp. & 2.29 & + & Choroterpes picteti & 1.04 & + \\
\hline Hydropsyche sp. 2 & 2.25 & + & Micronecta scholtzi & 0.96 & + \\
\hline Leuctra geniculata & 2.18 & + & Ecdyonurus gr. venosus & 0.87 & - \\
\hline Baetis rhodani & 2.08 & - & Platycnemis latipes/acutipennis & 0.81 & + \\
\hline Boyeria irene & 1.98 & + & Gomphus pulchelus & 0.81 & + \\
\hline Caenis luctuosa & 1.84 & - & Simuliidae gen. sp. & 0.77 & + \\
\hline Hydraena sp. & 1.83 & - & Laccophilus sp. & 0.76 & + \\
\hline Leuctra aurita & 1.70 & + & Gerris sp. & 0.74 & + \\
\hline Simuliidae gen. sp. & 1.52 & - & Cloeon gr. simile & 0.67 & + \\
\hline Sericostoma sp. 1 & 1.50 & + & & & \\
\hline Rhyacophila sp. 1 & 1.43 & + & & & \\
\hline Diptera pupae & 1.42 & - & & & \\
\hline Elmis sp. & 1.32 & - & & & \\
\hline Orectochilus villosus & 1.18 & - & & & \\
\hline Ancylus fluviatilis & 1.17 & - & & & \\
\hline Mystacides azurea & 1.13 & - & & & \\
\hline Ephemerella ignita & 1.12 & - & & & \\
\hline Polycentropus flavomaculatus & 1.00 & - & & & \\
\hline Allogamus ligonifer & 0.99 & + & & & \\
\hline Lumbriculidae gen. sp. & 0.93 & - & & & \\
\hline Epeorus silvicola & 0.80 & + & & & \\
\hline Dixidae gen. sp. & 0.72 & - & & & \\
\hline Baetis sp. 2 & 0.63 & + & & & \\
\hline Aphelocheirus occidentalis & 0.63 & + & & & \\
\hline Calopteryx virgo & 0.59 & + & & & \\
\hline Limnius sp. & 0.58 & + & & & \\
\hline Leuctra fusca & 0.54 & + & & & \\
\hline Protonemura meyeri & 0.52 & + & & & \\
\hline Gerridae gen. sp. & 0.43 & - & & & \\
\hline Baetis fuscatus & 0.40 & - & & & \\
\hline Dupophilus brevis & 0.40 & + & & & \\
\hline
\end{tabular}

The signals + (increase) or - (decrease) in column "Abundance class" indicate which species are more or less abundant in reference or impaired sites 
accounted for $90 \%$ of the dissimilarity between reference and impaired sites, and $74(18 \%$ of the total of species) contributed for $66 \%$ of the dissimilarity. SIMPER results of reference versus impaired sites (Fig. 3; Table 2) correspond with the pattern observed in the previous analyses. A value of $79.89 \%$ dissimilarity between the most and the least disturbed sites confirms that these reference and impaired sites groups are truly distinct despite strong interannual variation. These observations correspond with our initial findings, based on groups established using physicochemical data.

Principal representative macroinvertebrate taxa of the reference and impaired groups (to a cumulative percentage of $90 \%$ ) are presented in Tables 3 and 4. Reference sites are typified by intolerant species belonging to Trichoptera, Ephemeroptera, Plecoptera, Coleoptera, and Heteroptera such as Calamoceras marsupus (Brauer), Sericostoma sp. (Latreille), Allogamus ligonifer (McLachlan), Habrophlebia eldae (Jacob and Sarton), Ecdyonurus gr. venosus (Fabricius), Leuctra aurita (Navas), Protonemura meyeri (Pictet), Oulimnius sp. (Gozis), Elmis sp. (Latreille), Limnius sp. (Illiger), Dupophilus brevis (Mulsant), Aquarius najas (Degeer), and Aphelocheirus occidentalis (Nieser and Millán; Table 4). Disturbed sites are characterized almost exclusively by tolerant species from across several orders such as Diptera, Ephemeroptera, Trichoptera, and Heteroptera Table 4. On the other hand, the species that most contributed to dissimilarities between reference and impaired sites were associated to intolerant species (e.g., Leuctra sp., Sericostoma sp., C. marsupus, A. najas, Brachycentrus subnubilus). Only $15 \%$ of the total of the species data (65 species) had contributed with $2 / 3$ to the dissimilarities among sites.

\section{Metric selection}

A consistent pattern of disturbance in the ordination space was displayed by DCA analyses for each year, i.e., sites were distributed in the same order along the disturbance gradient. The Pearson coefficients of first axes correlations with all potential untransformed metrics showed a positive

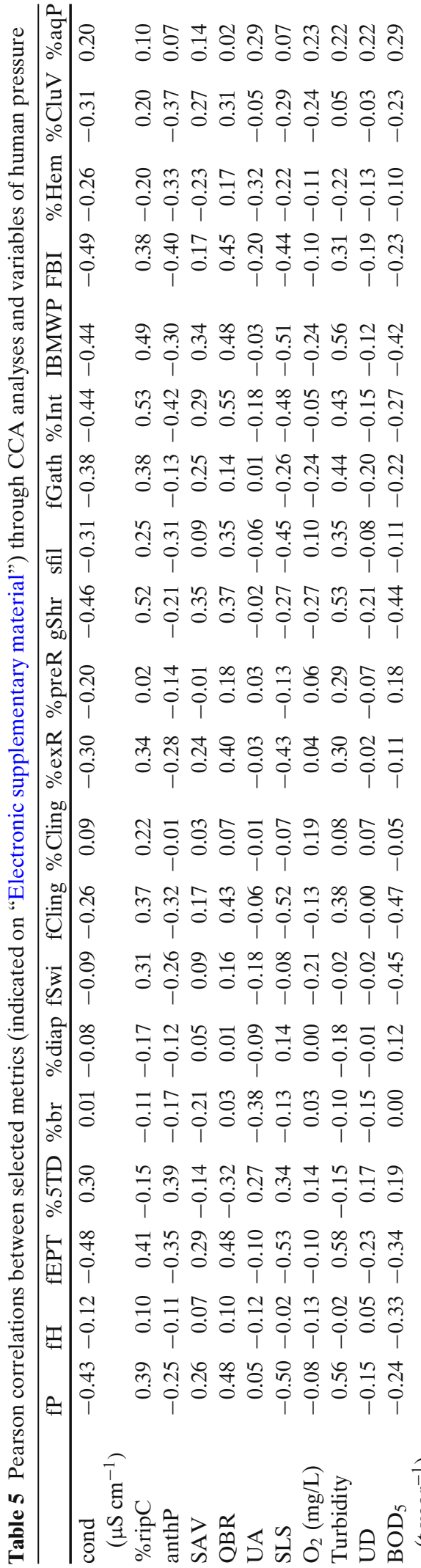

तิ ลิ กิ กั่ กั่ กิ กิ กิ 0 으으으

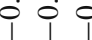
થิ તิ થิ $\dot{i} \hat{i} \dot{0}$ ใ. ใ ใ 0 $\hat{ָ} \hat{ก}$ i 1 i สิ สี O $==$ i 㠻寺㠻 i 100 $\stackrel{\infty}{\rightarrow} \underset{\sim}{=}$

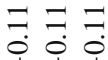
11 ?c:

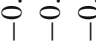
手守守 i 1 i 的品骂 i $\begin{array}{ll}1 & 0 \\ 0 & 0\end{array}$ $\because \simeq \simeq$

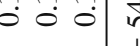
\begin{tabular}{lll}
8 & 8 & 8 \\
\hdashline & 0 & 0 \\
0
\end{tabular} 근

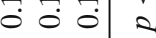
मे से मे $\dot{i} \hat{i} \quad$ $m m m$ i 1 i 莳莳古 i 1 i ชิ $\widetilde{T}$ むँ $\Rightarrow \geqslant \geqslant 0$ E $已$ $=$ 
association between the obtained metric score and increased perturbation and vice versa.

From the original group of 184 metrics, a subset of 78 attributes met the criteria of low reference site within-site variability (low CVs). Inspection of zeros and low values in reference sites further refined this selection ("Electronic supplementary material").

CCA analysis, including typological covariables following forward selection, resulted in 32 metrics that made a significant contribution $(p<0.05)$ and were independent of natural variability. Examination of VIFs of the successive CCAs analyses removed another 12 attributes.
The Pearson correlation coefficients for the 20 retained metrics (Table 5) showed that only \% diap and \% Cling showed no association with the selected disturbance variables (Table 5). Despite this, we retained all 20 metrics for further analysis, since they may have responded to variables that were not considered in this study. Examination of the boxplots revealed 12 the 20 retained candidate metrics to have little or no overlap between most disturbed and reference sites, satisfying the last metric selection criteria (Fig. 4). These included three structural metrics (fP, fEPT, and \%5TD), seven adaptation metrics (fSwi, fCling, \% exR, gShr, sFil, and fGath), and three metrics that
Fig. 4 Box plots of macroinvertebrate metrics selected by CCA for reference and impaired sites, obtained separately for 1997 and 2000. Boxes are interquartile ranges (25\% ile and $75 \%$ ile), range bars show maximum and minimum of nonoutliers, small squares are medians, and dots are outliers
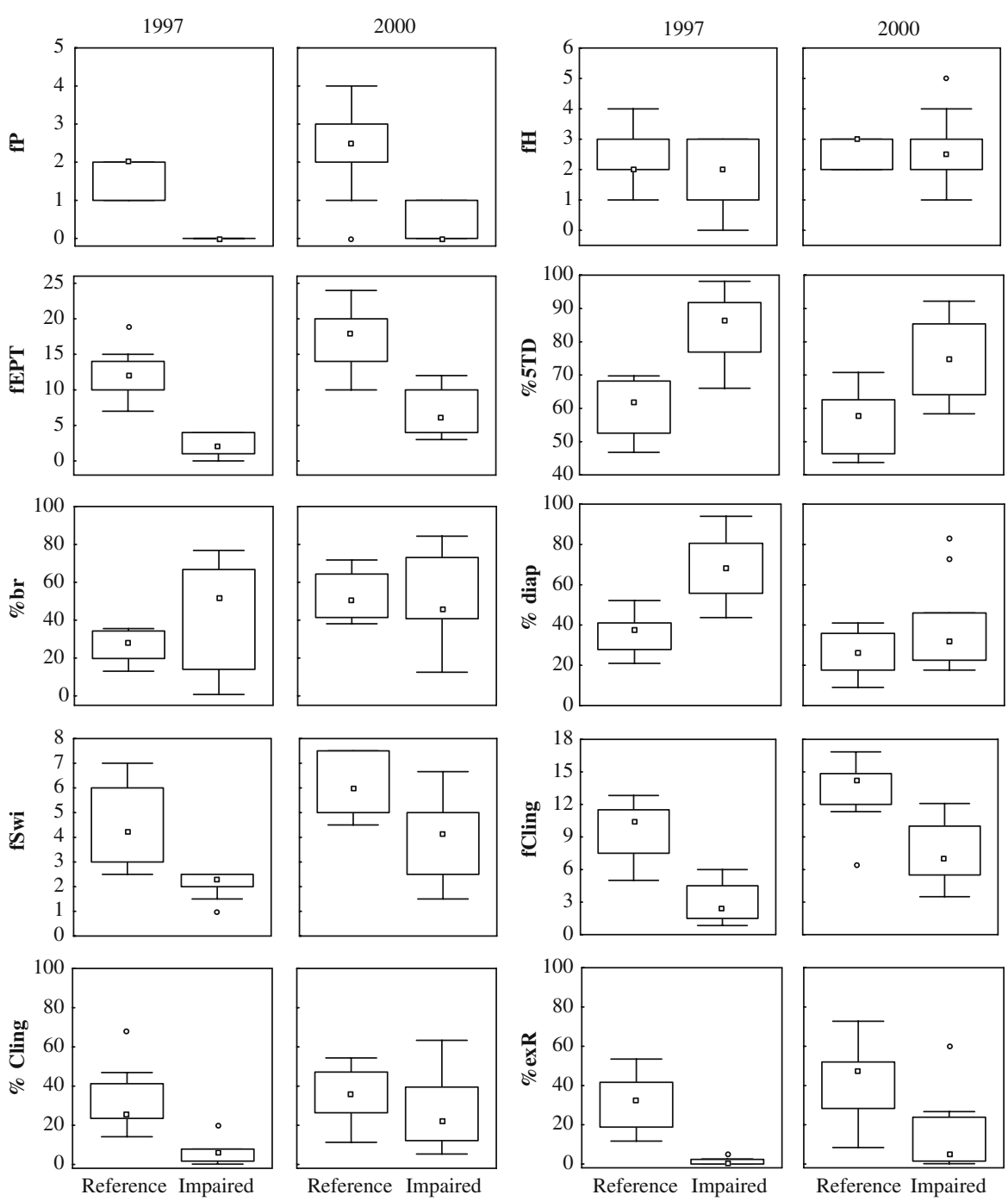
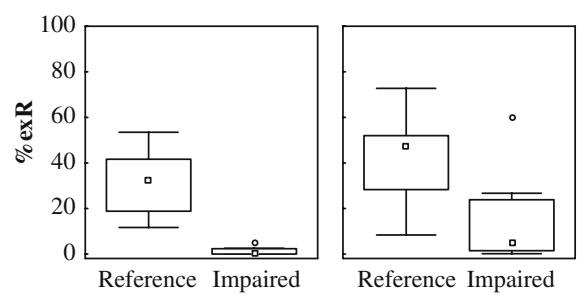
Fig. 4 (continued)
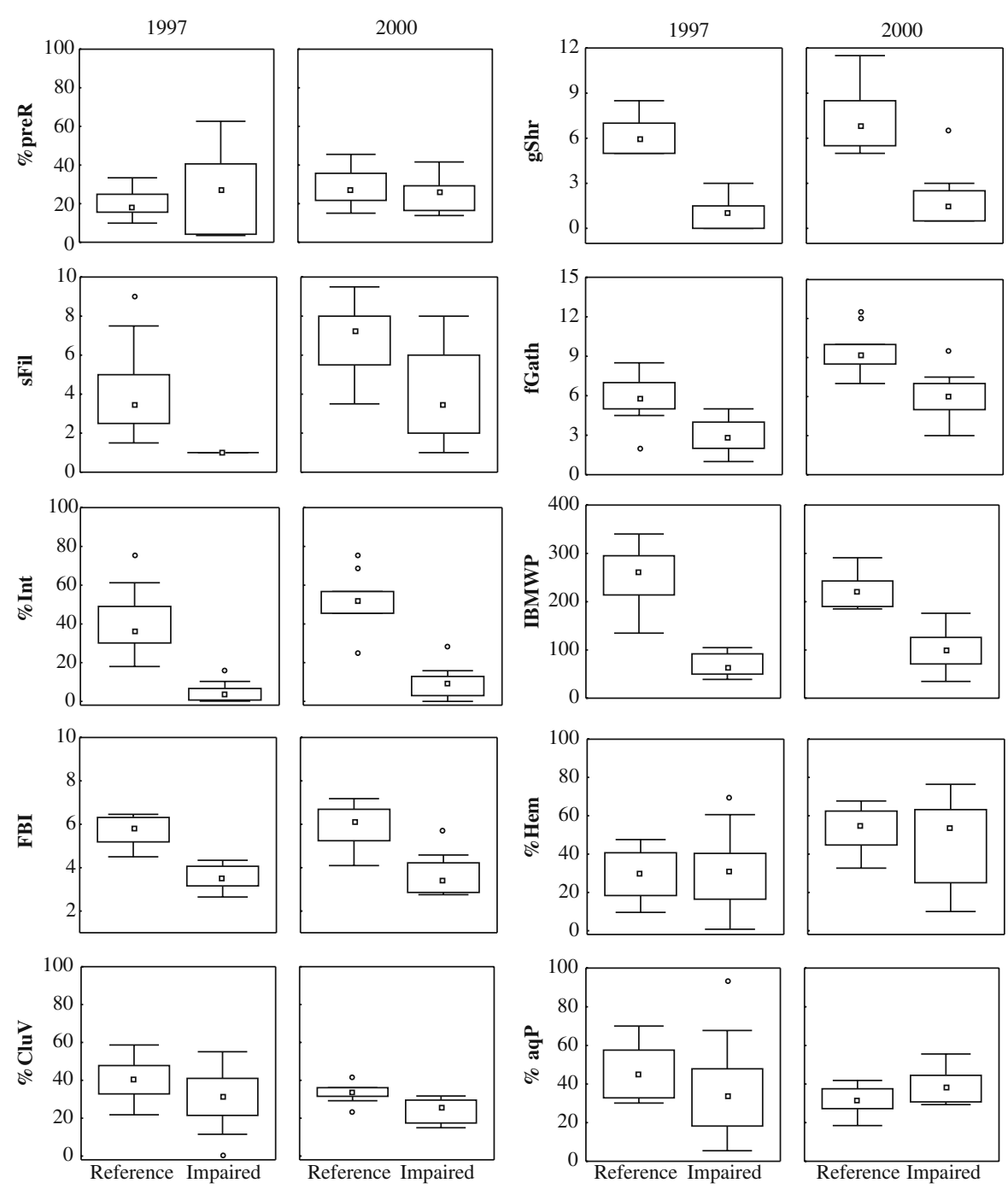

measure the tolerance level (\%Int and two indices: IBMWP and FBI).

\section{Discussion}

To identify human impacts on aquatic assemblages, measurements of the individual, community coupled with landscape level scales are required (Butcher et al. 2003) ensuring that when metrics are organized and selected systematically within a regional framework, multimetric indices effectively measure changes along perceived disturbance gradients (Karr and Chu 1999). This study included a large variety of point and nonpoint-source disturbances, including agri- culture, pasture, deforestation and afforestation, physical alterations of riparian and instream habitats, road building, impoundments, urban areas, and mining. Ecological condition was described by a large array of metrics (functional characteristics, i.e., traits, and attributes derived from structural and condition aspects of communities) in order to identify which best assess impairment. In particular, we wanted to test the possibility of integrating biological attributes into an assessment system.

In this study, it was verified an interannual variability (Table 2; Fig. 3). These differences between years (1997 versus 2000) could be explained by the weather conditions over the analyzed period that corresponded to extreme events, such as droughts and floods. The year of 1997 was one of the fifth 
hotter years of the last 150 years, and conversely, the winter of 2000 was the third rainiest of the last 30 years. Temporally, heterogeneous environment is an event which communities are naturally dependent (Poof and Ward 1989; Hildrew and Giller 1994). According to Minshall (1988), changes in flow, light, temperature, resource supply, and many other variables can occur over time scales, with varying degrees of predictability Poff (1992). However, in spite of the observed temporal changes in macroinvertebrate communities as a result of natural environmental variability, differences in spatial distribution of sampling sites across each year were not manifested for both years. Observing NMDS ordination and SIMPER analyses (Fig. 3; Table 2), the same environmental gradient structuring the characteristics of sites and the species occurring in them becomes clear. As a result, we can conclude that the dynamic nature of both environmental conditions and community structure in lotic environments do not have major effects on the sensitivity of the species and consequently in the sensitivity of this method.

Our results showed that 12 attributes successfully distinguished between the reference and impaired sites and also emphasized the value of combining conventional metrics (abundance and/ or richness of species, biotic indices, and tolerance measures) with biological traits (habit/behavior measures, habitat preference, and trophic groups) for reliable lotic biomonitoring. Fifty percent of the selected metrics were traits related to locomotion (2), preference of species in terms of current velocity (1), and functional feeding groups (3). Similar to other studies (Dolédec et al. 1999; Poff 1997), our results confirm that, in the catchment context, species traits can be used to assess stress magnitude in running waters and have considerable potential as a benchmark for biomonitoring and improving the traditional biomonitoring approach. Rodgers et al. (1979) stressed that the integration of structural/compositional and functional metrics provides the best mean of assessing impairment. Phillips (2004) notes that, rather than simply record loss or reduction in numbers of species as a result of a disturbance, use of species traits allows us to identify the most sensitive life history characteristics. In an attempt to use the functional characteristics of lotic macroinverte- brates for biomonitoring, Charvet et al. (1998) and Dolédec et al. (1999) found that the use of a large variety of biological traits was more reliable than community structure in detecting stream pollution in terms of species composition and abundances. Also, Charvet et al. (2000) concluded that community structure based on biological traits, unlike taxonomic composition, was relatively stable across large environmental gradients (geology, altitude, geographical coordinates, stream order, and slope) enabling the use of these descriptors for biomonitoring over large geographic regions. According to Phillips (2004), another benefit of using complementary species traits is their stability through space and time, unlike species composition. Vieira et al. (2006) refer as well that once some functional traits may not be constrained by taxonomy, they can be applicable at multiple spatial scales (local, regional, and continental) and can provide a consistent method for assessing community responses to environmental gradients. Thus, it becomes evident that assessment protocols based solely only on conventional attributes may not be sufficiently sensitive to distinguish impairment, whereas trait-based variables can detect problems that may otherwise be overlooked.

Over the last decade, the use of species traits has become more important in assessing stream system disturbance (Metcalfe 1989; Townsend and Hildrew 1994; Dolédec et al. 1996, 1999; Mabry et al. 2000; Ribera et al. 2001; Statzner et al. 2001a; Bady et al. 2005; Dziock et al. 2006). However, only a very small group of traits has been studied in combination with taxonomic indicators to produce macroinvertebrate based indices for biocriteria and assessment (Barbour et al. 1996; Fore et al. 1996; Kerans and Karr 1994). This paper has presented a heuristic framework that seeks, through a vast group of conventional metrics and species traits, to choose the best combinations of attributes for multiscale and cumulative disturbance effects with a view to integrate this approach into future monitoring systems. There is, however, a lack of information for many endemic invertebrate species concerning individual autecology (morphological and life history) and we support Poff's (1997) comments that more research is needed to quantify species traits in stream organisms in order to obtain important 
biological insights and better understanding of species-environmental relations. For this reason, future studies should focus on the documentation of clear relationships between biological traits and different human impacts on macroinvertebrates of running waters.

Our examination of all selected metrics has shown that "conventional", well-tested, and used water quality assessment metrics such as the biotic indices IBMWP and FBI make a highly significant contribution to this work. These indices are based on the detection of organic pollution, based on a community's response to high organic loading and decreased dissolved oxygen levels. Despite of some selected metrics have been developed solely for assessing organic pollution, many also can be used to define the tolerance of species to other human impacts. For example, species richness of Ephemeroptera, Plecoptera, and Trichoptera groups decreases not only with an increase of nutrient concentration (Barbour et al. 1996; Bratton et al. 1980; Fitzpatrick et al. 2001) but also with an increase of contaminants, heavy metals, thermal pollution (Lillie et al. 2003), flow disruption (Fitzpatrick et al. 2001; Lillie et al. 2003), sediment input (Lenat 1984; Meban 2001; Quinn and Hickey 1990), acid rain (Peterson and Van Eeckhaute 1992), and acid mine drainage (Zarger et al. 1986). Plecoptera (fP) are among the most sensitive indicator organisms and can indicate impairment resulting from low dissolved oxygen or siltation (Chirhart 2003). Measures of tolerance, such as \% Int, indicate sensitivity of the assemblage and component species to various types of perturbation (Hilsenhoff 1987). According to Chirhart (2003), the presence of moderate numbers of intolerant taxa is an indicator of good aquatic health. Trophic and functional benthic structure measures (e.g., gShr, sFil, and fGath) are also useful since they are influenced by nutrient enrichment (Fitzpatrick et al. 2001; Quinn and Hickey 1990), disturbance of riparian corridors (Cummins 1973; Cummins et al. 1989), and impoundment and regularization (Cortes et al. 2002a; Voelz and Ward 1991). Concerning dominance measures and despite the difficulty of providing guidelines for interpreting a community structure because of the existence of a myriad of natural communities (Lillie et al. 2003), results have shown that the percentage of a dominant organism increases with increasing perturbation (Barbour et al. 1996; Chirhart 2003) notwithstanding they are not particularly sensitive to moderate amounts of organic or toxic loadings (Plafkin et al. 1989). The percent contribution of dominant taxon metric (\%5TD) proved to be a good indicator in our study area. Regarding habitat preference, Vieira et al. (2004) verified that rheophily and microhabitat preferences may be indicative of hydrological disturbance after a wildfire. Rheophilous taxa has been also associated to small rivers without organic pollution (UsseglioPolatera et al. 2000) confirming, this way, the ability of metrics like \% exR in discriminating impairment.

It was difficult to establish a cause-effect relationship between traits that describe habitat/behavior (fSwi, fCling) and environmental variables due to the scarcity of information. However, Charvet et al. (1998) mention that mobility via swimming may be sensitive to chemical contamination, and Chirhart (2003) highlights that a lack of clinger taxa can indicate siltation or substrate embeddedness as a result of erosion.

From all tested functional traits, only trophicbased and locomotion traits could distinguished between reference and disturbed sites. Previous studies from temperate zone frequently found that life-history-related traits (e.g., number of descendants per reproductive cycle, number of reproductive cycles/individual, life duration of adults) responded best to a range of anthropogenic stressors and those traits related to feeding strategies, body shape, and respiration generally were more weakly related to perturbations (Dolédec et al. 1999, 2006). A possible explanation for the absence of response in our study to life-historyrelated traits is that it is related to ecoregions. Portugal, inserted in the biogeographic region of Iberian Peninsula according to Illies (1978) and WFD (Annex XI), is a region with very different characteristics from those where the referred studies took place. In spite of trait-based approaches rely on evolutionary responses to environmental selective forces across broad geographical gradients (Dolédec and Statzner 2008), Dolédec et al. (1999) refer that this type of traits can be constrained by geographic latitude and alerts that 
the future studies have to show over which geographic range such a trait may serve in biomonitoring. Moreover, our rivers are much less impacted than the studied large rivers in midEurope that have been largely altered by human activities. This could be another answer once the diverse expected communities has different lifehistory strategies and functional responses to major environmental characteristics that in our study did not reveal to be responsive to perturbation.

From the 12 retained metrics, 11 need to be identified to family or genus levels and only one needs the species-level resolution (sFil). This last one is a trait related to feeding strategies. In agreement with Dolédec et al. $(1998,2000)$ and Gayraud et al. (2003), trait-based approaches using higher levels of taxonomic identification (for example, genus and family) may adequately describe trait occurrence and may be more time efficient. Moulton et al. (2000) also refers that trait-based metrics also may be robust to taxonomic ambiguities, which can influence how taxonomically based metrics respond to environmental gradients. Thus and according to these authors, we think that the best basis for assemblage description must be one of these two taxonomic levels or both, genus and family levels.

Consequent evaluations suggest that the selected metrics are good indicators of water quality in the Douro catchment since they describe most of the variation verified in invertebrate assemblages and distinguish between different environmental conditions. The present set of metrics has the advantage of integrating traits with "conventional" metrics, which makes them potentially able to assess multiscale effects, knowing that the human impacts acting at higher scales are successively modified (filtered) by local variables (Frissell et al. 1986; Poff 1997). Thus, this approach provides a starting point for the selection of metrics that can be reliably applied to larger geographical areas beyond the river basin. Following screening and validation across a gradient of human influence, these metrics could be used in a refined index to better characterize community responses to general environmental degradation. Additionally, this information can be a baseline for developing strategies for the biomonitoring of aquatic ecosystem health and provide information relevant to WFD, more specifically, with regard to its application in Portugal. Thus, the set of traits selected in this work could be used also to define assemblage types and determine expected biological conditions at reference sites for biomonitoring programs in a similar way to the ones that has been used at other European countries (Dolédec et al. 1999, 2000; Charvet et al. 2000; Statzner et al. 2001b; Dziock 2006; Henle et al. 2006; Dolédec and Statzner 2008).

Acknowledgment Samantha J. Hughes (Centre for Macaronesian Studies, University of Madeira; Forest Research Centre, Technical University of Lisbon) provided comments on the first draft of this article and helped to improve the English.

\section{References}

Alba-Tercedor, J. (2000). BMWP', un adattamento spagnolo del British Biological Monitoring Working Party (BMWP) Store System. Biologia Ambientale, 14(2), 65-67.

Alba-Tercedor, J., \& Sanchez-Ortega, J. A. (1988). Un método rápido y simple para evaluar la calidad biologica de las aguas Corrientes basado en de Hellawell, 1978. Limnetica, 4, 51-56.

Askew, R. R. (1988). The dragonflies of Europe (291 pp). Colchester: Harley Books.

Bady, P., Dolédec, S., Fesl, C., Gayraud, S., Bacchi, M., \& Schöll, F. (2005). Use of invertebrate traits for biomonitoring of European large rivers: The effects of sampling effort on genus richness and functional diversity. Freshwater Biology, 50, 159-173. doi:10.1111/ j.1365-2427.2004.01287.x.

Barbour, M. T., \& Yoder, C. O. (2000). The multimetric approach to bioassessment, as used in United States of America. In J. F. Wright, D. W. Sutcliffe, \& M. T. Furse (Eds.), Assessing the biological quality of fresh waters (pp. 281-292). Ambleside: The Freshwater Biological Association.

Barbour, M. T., Stribling, J. B., \& Karr, J. R. (1995). The multimetric approach for establishing biocriteria and measuring biological condition. In W. S. Davis \& T. P. Simon (Eds.), Biological assessment and criteria: Tools for water resource planning and decision-making (pp. 63-77). London: Lewis.

Barbour, M. T., Gerritsen, J., Griffith, G. E., Frydenborg, R., McCarron, E., White, J. S., et al. (1996). A framework for biological criteria for Florida streams using benthic macroinvertebrates. Journal of the North American Benthological Society, 15, 185-211. doi:10.2307/1467948.

Barbour, M. T., Gerritsen, J., Snyder, B. D., \& Stribling, J. B. (1999). Rapid bioassessment protocols for use in streams and wadeable rivers: Periphyton, benthic 
macroinvertebrates and fish (2nd ed.). EPA 841-B-99002. Washington, DC: U.S. Environmental Protection Agency, Office of Water.

Bonada, N., Dolédec, S., \& Statzner, B. (2007). Taxonomic and biological trait differences of stream macroinvertebrate communities between Mediterranean and temperate regions: Implications for future scenarios. Global Change Biology 13, 1658-1671.

Bonada, N., Prat, N., Resh, V. H., \& Statzner, B. (2006). Development in aquatic insect biomonitoring: A comparative analysis of recent approaches. Annual Review of Entomology, 51, 495-523. doi:10.1146/annurev. ento.51.110104.151124.

Bratton, S. O., Mathews, R. C., \& White, P. S. (1980). Agricultural area impacts within a natural area: Cade's Cove, a case history. Environmental Management, 4, 433-448. doi:10.1007/BF01869654.

Butcher, J. T., Stewart, P. M., \& Simon, T. P. (2003). A benthic community index for streams in the Northern lakes and forests ecoregion. Ecological Indicators, 3, 181-193. doi:10.1016/S1470-160X(03) 00042-6.

Charvet, S., Kosmala, A., \& Statzner, B. (1998). Biomonitoring through biological traits of benthic macroinvertebrates: Perspectives for a general tool in stream management. Archiv fuer Hydrobiologie, 142, 415-432.

Charvet, S., Statzner, B., Usseglio-Polatera, P., \& Dumonts, B. (2000). Traits of benthic macroinvertebrates in semi-natural French streams: An initial application to biomonitoring in Europe. Freshwater Biology, 43, 277-296. doi:10.1046/j.1365-2427.2000. 00545.x.

Chinery, M. (1992). Insects d'Europe: Multiguide nature (380 pp). Paris: Bordas.

Chirhart, J. (2003). Development of a macroinvertebrate index of biological integrity (MIBI) for rivers and steams of the St. Croix River Basin in Minnesota (41 pp). St. Paul, MN: Minnesota Pollution Control Agency, Biological Monitoring Program.

Clarke, K. R., \& Gorley, R. N. (2001). PRIMER v5: User manual/tutorial. Plymouth: PRIMER-E.

Clarke, K. R., \& Warwick, R. M. (2001). Change in marine communities: an approach to statistical analysis and interpretation (2nd ed.). Plymouth: Primer-e Ltd, Plymouth Marine Laboratory.

Cortes, R. M. V. (1992). Seasonal pattern of benthic communities along the longitudinal axis of river systems and the influence of abiotic factors on the spatial structure of those communities. Archiv fuer Hydrobiologie, $126,85-103$.

Cortes, R. M. V., Ferreira, M. T., Oliveira, S. V., \& Godinho, F. (1998). Contrasting impact of small dams on the macroinvertebrates of two Iberian mountain rivers. Hydrobiologia, 389, 51-61. doi:10.1023/ A:1003599010415.

Cortes, R. M. V., Ferreira, M. T., Oliveira, S. V., \& Oliveira, D. (2002a). Macroinvertebrate community structure in a regulated river segment with different flow conditions. River Research and Applications, 18, 367-382. doi:10.1002/rra.679.
Cortes, R. M. V., Oliveira, S. V., Cabral, D. A., Santos, S. \& Ferreira, T. (2002b). Different scales of analysis in classifying streams: From a multimetric towards an integrate system approach. Large Rivers 13. Archiv für Hydrobiologie Suppl., 141(3-4), 209-224.

Cummins, K. W. (1973). Trophic relations of aquatic insects. Annual Review of Entomology, 18, 183-206. doi:10.1146/annurev.en.18.010173.001151.

Cummins, K. W., Wilzbach, M. A., Gates, D. M., Perry, J. B., \& Taliaferro, W. B. (1989). Shredders and riparian vegetation. Bioscience, 39, 24-30. doi:10.2307/ 1310804.

Davis, W. S., Snyder, B. D., Stribling, J. B., \& Stoughton, C. (1996). Summary of state biological assessment programs for streams and rivers. EPA 230-R-96-007. Washington, DC: Office of Planning, Policy, and Evaluation, US Environmental Protection Agency.

De Pauw, N., \& Vanhooren, G. (1983). Method for biological quality assessment of watercourses in Belgium. $\mathrm{Hy}$ drobiologia, 100, 153-168. doi:10.1007/BF00027428.

Dolédec, S., Chessel, D., \& Ter Braak, C. J. F. (1996). Matching species traits to environmental variables. Environmental and Ecological Statistics, 3, 143-166. doi:10.1007/BF02427859.

Dolédec, S., Olivier, J. M., \& Statzner, B. (2000). Accurate description of the abundance of taxa and their biological traits in stream invertebrate communities-effects of taxonomic and spatial resolution. Archiv fuer Hydrobiologie, 148, 25-43.

Dolédec, S., Philips, N., Scarsbrook, M., Riley, R. H., \& Towsend, C. R. (2006). Comparison of structural and functional approaches to determining landuse effects on grassland stream invertebrate communities. Journal of the North American Benthological Society, 25(1): 44-60. Cote bibliothèque 06.3.

Dolédec, S., \& Statzner, B. (2008). Invertebrate traits for the biomonitoring of large European rivers: An assessment of specific types of human impact. Freshwater Biology, 53, 617-634. doi:10.1111/j.1365-2427. 2007.01924.x.

Dolédec, S., Statzner, B., \& Bournard, M. (1999). Species traits for future biomonitoring across ecoregions: Patterns along a human-impacted river. Freshwater Biology, 42, 737-758. doi:10.1046/j.1365-2427. 1999.00509.x.

Dolédec, S., Statzner, B., \& Frainay, V. (1998). Accurate description of functional community structure: Identifying stream invertebrates to species-level? Bulletin of the North American Benthological Society, 15, 154-155.

Dziock, F. (2006). Life-history data in bioindication procedures, using the example of Hoverflies (Diptera, Syrphidae) in the Elbe floodplain. International Review of Hydrobiology, 91, 341-363. doi:10.1002/iroh. 200510889.

Dziock, F., Henle, K., Foeckler, F., Follner, K., \& Scholz, M. (2006). Biological indicator systems in floodplaina review. International Review of Hydrobiology, 91, 271-291. doi:10.1002/iroh.200510885.

European Commission (2000). The European Water Framework Directive 2000/60/CE (WFD) of 23 
October 2000 establishing a framework for a community policy in the domain of water. Official Journal of European Communities, L327, 1-72.

Faessel, B. (1985). Les Trichoptères. Données biologiques, éthologiques et écologiques. Clés de détermination larvaire des familles et des principaux genres de France. Bulletin Francais de la Peche et de la Pisciculture, 299, 1-41. doi:10.1051/kmae:1985001.

FAME Consortium (2004). Manual for the application of the European Fish Index-EFI. A fish-based method to assess the ecological status of European rivers in support of the Water Framework Directive. Version 1.1. http://fame.boku.ac.at.

Fitter, R., \& Manuel, R. (1994). Lakes, rivers, streams and ponds of Britain and North-West Europe: Collins Photo Guide (382 pp). London: Harper Collins.

Fitzpatrick, F. A., Scudder, B. C., Lenz, B. N., \& Sullivan, D. J. (2001). Effects of multi-scale environmental characteristics on agricultural stream biota in eastern Wisconsin. Journal of the American Water Resources Association, 37, 1489-1507. doi:10.1111/j. 1752-1688.2001.tb03655.x.

Fore, L. S., Karr, J. R., \& Wisseman, R. W. (1996). Assessing invertebrate responses to human activities: Evaluating alternative approaches. Journal of the North American Benthological Society, 15, 212-231. doi:10.2307/1467949.

Frissell, C. A., Liss, W. J., Warren, C. E., \& Hurley, M. D. (1986). A hierarchical framework for stream habitat classification: Viewing streams in the watershed concept. Environmental Management, 10, 199214. doi:10.1007/BF01867358.

Gayraud, S., Statzner, B., Bady, P., Haybachp, A., Sholl, F., Usseglio-Polatera, P., et al. (2003). Invertebrate traits for the biomonitoring of large European rivers - an initial assessment of alternative metrics. Freshwater Biology, 48, 2045-2064. doi:10.1046/j.13652427.2003.01139.x.

Henle, K., Dziock, F., Foeckler, F., Follner, K., Hüsing, V., Hettrich, A., et al. (2006). Study design for assessing species environment relationships and developing indicator systems for ecological changes in floodplains - the approach of the RIVA Project. International Review of Hydrobiology, 91, 292-313. doi:10.1002/iroh.200610886.

Hildrew, A. G., \& Giller, P. S. (1994). Patchiness, species interactions and disturbance in the stream benthos. In P. S. Giller, A. G. Hildrew, \& D. G. Raffaelli (Eds.), Aquatic ecology: Scale, pattern and process (pp. 2162). London: Blackwell Scientific.

Hill, M. O. (1973). Diversity and evenness: A unifying notation and its consequences. Ecology, 54, 427-432. doi:10.2307/1934352.

Hill, M. O. (1979). DECORANA-A FORTRAN program for detrended correspondence analyses and reciprocal averaging (p. 95). Ithaca, NYY: Cornell University.

Hill, M. O., \& Gauch, H. G. (1980). Detrended correspondence analysis, an improved ordination technique. Vegetatio, 42, 47-48. doi:10.1007/BF00048870.

Hilsenhoff, W. L. (1987). An improved index of organic stream pollution. Great Lakes Entomologist, 20, 31-39.
Hilsenhoff, W. L. (1988). Rapid field assessment of organic pollution with a family-level biotic index. Journal of the North American Benthological Society, 7, 65-68. doi:10.2307/1467832.

Hynes, H. B. N. (1979). The ecology of running waters $\left(3^{a}\right.$ ed., p. 555). Liverpool: Liverpool University Press.

Illies, J. (Ed.) (1978). Limnofauna Europaea (2nd ed.). Stuttgart: G. Fischer.

Illies, J., \& Botosaneanu, L. (1963). Problèmes et méthodes de la classification et de la zonation écologique des eaux courantes, considérées surtout du point de vue faunistique. Verhandlungen - Internationale Vereinigung für Theoretische und Angewandte Limnologie, 12, 1-57.

Karr, J. R. (1991). Biological integrity: A long neglected aspect of water resource management. Ecological Applications, 1, 66-84. doi:10.2307/1941848.

Karr, J. R., \& Chu, E. W. (1999). Restoring life in running waters: Better biological monitoring. Covelo, CA: Island.

Karr, J. R., Fausch, K. D., Angermeier, P. L., Yant, P. R., \& Schlosser, I. J. (1986). Assessing biological integrity in running waters: A method and its rationale. Special publication 5. Urbana: Illinois Natural History Survey.

Kashian, D. R., \& Burton, T. M. (2000). A comparison of macroinvertebrates of 2 Great Lakes Coastal Wetlands: Testing potential metrics for an index of ecological integrity. Journal of Great Lakes Research, 26, 460-481.

Kerans, B. L., \& Karr, J. R. (1994). A benthic index of biotic integrity (B-IBI) for rivers of the Tennessee Valley. Ecological Applications, 4, 768-785. doi: 10.2307/1942007.

Lenat, D. R. (1984). Agriculture and stream water quality: A biological evaluation of erosion control procedures. Environmental Management, 8, 333-343. doi:10.1007/BF01868032.

Lenat, D. R. (1993). A biotic index for the southeastern United States: Derivation and list of tolerance values, with criteria for assigning water-quality ratings. Journal of the North American Benthological Society, 12, 279-290. doi:10.2307/1467463.

Lillie, R. A., Szczytko, S. W., \& Miller, M. A. (2003). Macroinvertebrate data interpretation guidance manual. Madison: Wisconsin Department of Natural Resources.

Mabry, C., Ackerly, D., \& Gerhardt, F. (2000). Landscape and species-level distribution of morphological and life history traits in a temperate woodland flora. Journal of Vegetation Science, 11, 213-224. doi:10.2307/3236801.

Margalef, R. (1951). Diversidad de especies en las comunidades naturales. Publicaciones del Instituto de Biologia Aplicada, Barcelona, 6, 59-72.

Margalef, R. (1983). Limnologia. Barcelona: Omega.

Meban, C. A. (2001). Testing bioassessment metrics: Macroinvertebrate, sculpin, and salmonid responses to stream habitat, sediment, and metals. Environmental Monitoring and Assessment, 67, 293-322. doi:10.1023/A:1006306013724. 
Merritt, R. W., \& Cummins, K. W. (1996). An introduction to the aquatic insects of North America (2nd ed.). Dubuque, IA: Kendall.

Metcalfe, J. L. (1989). Biological water quality assessment of running waters based on macroinvertebrate communities: History and present status in Europe. Environmental Pollution, 60, 101-139. doi:10.1016/ 0269-7491(89)90223-6.

Minshall, G. W. (1988). Stream ecosystem theory: A global perspective. Journal of the North American Benthological Society, 7, 263-288. doi:10.2307/1467294.

Monzón, A. (1996). Caracterización limnológica de los macroinvertebrados fluviales de la cuenca del río Tua (Cuenca del Duero, Portugal) (313 pp). Ph.D. thesis, UTAD, Vila Real.

Moulton, S. R., Carter, J. L., Grotheer, S. A., Cuffney, T. F., \& Short, T. M. (2000). Methods for analysis by the U. S. Geological Survey National Water Quality Laboratory - processing taxonomy, and quality control of benthic macroinvertebrate sample (49 pp). U.S. Geological Survey Open-File Report 00-212.

Munné, A., Prat, N., Solá, C., Bonada, N., \& Rieradevall, M. (2003). A simple field method for assessing the ecological quality of riparian habitat in rivers and streams: QBR index. Aquatic Conservation: Marine \& Freshwater Ecosystems, 13, 147-163. doi:10.1002/aqc.529.

Niemi, G. J., \& McDonald, M. E. (2004). Application of ecological indicators. Annual Review of Ecology Evolution and Systematics, 35, 89-111. doi:10.1146/ annurev.ecolsys.35.112202.130132.

Nieser, N., Baena, M., Martinez-Aviles, J., \& Millan, A. (1994). Claves para la identificación de los heterópteros acuáticos (nepomorpha \& gerromorpha) de la Península Ibérica-Con notas sobre las especies de las Islas Azores, Baleares, Canarias y Madeira. N. Prat (Ed.). Madrid: Asociación Española de Limnologia.

Norris, R. N. (1995). Biological monitoring: The dilemma of data analysis. Journal of the North American Benthological Society, 14, 440-450. doi:10.2307/1467210.

Oliveira, S. V., \& Cortes, R. M. V. (2006). Combining logistic models with multivariate methods for the rapid biological assessment of rivers using macroinvertebrates. Environmental Monitoring and Assessment, 112, 93-113. doi:10.1007/s10661-006-0766-5.

Palmer, C. G., Maart, B., Palmer, A. R., \& O'Keeffe, J. H. (1996). An assessment of macroinvertebrate functional feeding groups as water quality indictors in the Buffalo River, Eastern Cape Province, South Africa. Hydrobiologia, 318, 153-164. doi:10.1007/ BF00016677.

Peeters, E. T. H. M. (2001). Benthic macroinvertebrates and multiple stressors-quantification of the effects of multiple stressors in field laboratory and model settings (168 pp). Ph.D. thesis. Wageningen University, The Netherlands.

Peterson, R. H., \& Van Eeckhaute, L. (1992). Distributions of Ephemeroptera, Plecoptera and Trichoptera of 3 maritime catchments differing in $\mathrm{pH}$. Freshwater Biology, 27, 65-78. doi:10.1111/j.1365-2427.1992.tb00523.x.

Phillips, N. (2004). Stream biomonitoring using species traits. In National Institute of Water and Atmospheric
Research (Eds.), Water and atmosphere (Vol. 12(4), pp. 8-9). Hamilton: National Institute of Water and Atmospheric Research.

Plafkin, J. L., Barbour, M. T., Porter, K. D., Gross, S. K., \& Hughes, R. M. (1989). Rapid bioassessment protocols for use in streams and rivers: Benthic macroinvertebrates and fish. EPA/444/4-89-001. Washington, DC: U.S. Environmental Protection Agency.

Poff, N. L. (1992). Why disturbances can be predictable: A perspective on the definition of disturbance in streams. Journal of the North American Benthological Society, 11, 86-92.

Poff, N. L. (1997). Landscape filters and species traits: Towards mechanistic understanding and prediction in stream ecology. Journal of the North American Benthological Society, 16, 391-409. doi:10.2307/1468026.

Poff, N. L., \& Allan, J. D. (1995). Functional organization of stream fish assemblages in relation to hydrologic variability. Ecology, 76, 606-627. doi:10.2307/1941217.

Poof, N. L., \& Ward, J. V. (1989). Implications of streamflow variability and predictability for lotic community structure: a regional analysis of streamflow patterns. Canadian Journal of Fisheries and Aquatic Sciences, 46, 1805-1818. doi:10.1139/f89-228.

Pont, D., Hugueny, B., Beier, B., Goffaux, D., Melcher, A., Noble, R., et al. (2006). Assessing river biotic condition at a continental scale: A European approach using functional metrics and fish assemblages. Journal of Applied Ecology, 43, 70-80. doi:10.1111/j. 1365-2664.2005.01126.x.

Quinn, J. M., \& Hickey, C. W. (1990). Characterization and classification of benthic invertebrate communities in 88 New Zealand rivers in relation to environmental factors. New Zealand Journal of Marine and Freshwater Research, 24, 387-409.

REFCOND (2003). Guidance on establishing reference conditions and ecological status class boundaries for inland surface waters. CIS working group 2.3. Final version 7.0.

Resh, V. H. (1994). Variability, accuracy, and taxonomic costs of rapid assessment approaches in benthic biomonitoring. Bollettino di Zoologia, 61, 375-383.

Reynoldson, T. B., Bailey, R. C., Day, K. E., \& Norris, R. H. (1995). Biological guidelines for freshwater sediment based on Benthic Assessment of Sediment (the BEAST) using a multivariate approach for predicting biological state. Australian Journal of Ecology, 20, 198-219. doi:10.1111/j.1442-9993.1995.tb00532.x.

Reynoldson, T. B., Norris, R. H., Resh, V. H., Day, K. E., \& Rosenberg, D. M. (1997). The reference condition: A comparison of multimetric and multivariate approaches to assess water-quality impairment using benthic macroinvertebrates. Journal of the North American Benthological Society, 16, 833-852. doi:10.2307/1468175.

Ribera, I., Dolédec, S., Downie, I. S., \& Foster, G. N. (2001). Effect of land disturbance and stress on species traits of ground beetle assemblages. Ecology, 82, 1112-1129.

Richoux, P. (1982). Coléoptères Aquatiques (Genres: Adultes et larves). In Introduction pratique a la 
systematique des organisms des eaux continentals Française 2 (p. 303). Bulletin de la Société Limnéenne de Lyon.

Rodgers, J. H., Dickson, K. L. Jr., \& Cairns, J. Jr. (1979). A review and analysis of some methods used to measure functional aspects of periphyton. In R. L. Weitzel (Ed.), Methods and measurements of periphyton communities: A review. Special technical publication 690. West Conshohocken, PA: American Society for Testing and Materials.

Shannon, C. E. (1948). A mathematical theory of communication. Bell System Techical Journal, 27, 379-423, 623-656.

Simpson, M., \& Norris, R. H. (2000). Biological assessment of river quality: Development of AUSRIVAS models and outputs. In J. F. Wright, D. W. Sutcliffe, \& M. T. Furse (Eds.), Assessing the biological quality of fresh waters-RIVPACS and other techniques. Ambleside: The Freshwater Biological Association.

Statzner, B., Resh, V. H., \& Roux, L. (1994). The synthesis of long term ecological research in the context of concurrently developed ecological theory: Design of a research strategy for the Upper Rhône River and its floodplain. Freshwater Biology, 31, 253-263. doi:10.1111/j.1365-2427.1994.tb01739.x.

Statzner, B., Bady, P., Dolédec, S., \& Schöll, F. (2005). Invertebrate traits for biomonitoring of large European rivers: An initial assessment of trait patterns in least impacted river reaches. Freshwater Biology, 50, 2136-2161. doi:10.1111/j.1365-2427.2005. 01447.x.

Statzner, B., Bis, B., Dolédec, S., \& Usseglio-Polatera, P. (2001a). Perspectives for biomonitoring at large spatial scales-a unified measure for functional composition of invertebrate communities in European running waters. Basic and Applied Ecology, 2, 73-85. doi:10.1078/1439-1791-00039.

Statzner, B., Hildrew, A. G., \& Resh, V. H. (2001b). Species traits and environmental constraints: Entomological research and the history of ecological theory. Annual Review of Entomology, 46, 291-316. doi:10.1146/annurev.ento.46.1.291.

Statzner, B., Hoppenhaus, K., Arens, M. F., \& Richoux, P. (1997). Reproductive traits, habitat use and templet theory: A synthesis of world-wide data on aquatic insects. Freshwater Biology, 38, 109-135. doi:10.1046/j.1365-2427.1997.00195.x.

Suter, G. W. (1993). A critique of ecosystem health concepts and indices. Environmental Toxicology and Chemistry, 12, 1533-1539. doi:10.1897/1552-8618 (1993)12[1533:ACOEHC]2.0.CO;2.

Tachet, H., Richoux, P., Bournaud, M., \& UsseglioPolatera, P. (2002). Invertébrés d'eau douce: Systématique, biologie, écologie, 2nd corrected impression. Paris: CNRS.

Ter Braak, C. J. F., \& Smilauer, P. (1998). CANOCO reference manual and user's guide to Canoco for Windows. Software for Canonical Community Ordination: version 4.0 (351 pp.). Wageningen: Centre for Biometry Wageningen.
Thorp, J. H., \& Covich, A. P. (1991). Ecology and classification of North American freshwater invertebrates. San Diego, CA: Academic.

Tomanova, S., Goitia, E., \& Helešic, J. (2006). Trophic levels and functional feeding groups of macroinvertebrates in neotropical streams. Hydrobiologia, 556, 251-264. doi:10.1007/s10750-005-1255-5.

Townsend, C. R., \& Hildrew, A. G. (1994). Species traits in relation to a habitat templet for river systems. Freshwater Biology, 31, 265-275. doi:10.1111/j.13652427.1994.tb01740.x.

Usseglio-Polatera, P., Bournaud, M., Richoux, P., \& Tachet, H. (2000). Biological and ecological traits of benthic freshwater macroinvertebrates: Relationships and definition of groups with similar traits. Freshwater Biology, 43, 175-205. doi:10.1046/j.13652427.2000.00535.x.

Van Haveren, B. P. (1986). Water resources measurements: A handbook for hydrologists and engineers. Denver, CO: American Water Works Association.

Vieira, N. K. M., Clements, W. H., Guevara, L. S., \& Jacobs, B. F. (2004). Resistance and resilience of stream insect communities to repeated hydrologic disturbances after a wildfire. Freshwater Biology, 49, 1243-1259. doi:10.1111/j.1365-2427.2004.01261.x.

Vieira, N. K. M., Poff, N. L., Carlisle, D. M., Moulton, S. R., II, Koski, M. L., \& Kondratieff, B. C. (2006). A database of lotic invertebrate traits for North America: U.S. Geological Survey Data Series 187. http://pubs.water.usgs.gov/ds187.

Vieira-Lanero, R. (2000). Las larvas de los Tricópteros de Galicia (Insecta: Trichoptera). Ph.D. thesis, Universidad de Santiago de Compostela, Spain. (606 pp).

Voelz, N. D., \& Ward, J. V. (1991). Biotic responses along the recovery gradient of a regulated stream. Canadian Journal of Fisheries and Aquatic Sciences, 48, 24772490.

Wetzel, R. G. (1993). Limnologia (919 pp). Lisboa: Fundação Calouste Gulbenkian.

Wright, J. F. (1995). Development and use of a system for predicting the macroinvertebrate fauna in flowing waters. Australian Journal of Ecology, 20, 181-197. doi:10.1111/j.1442-9993.1995.tb00531.x.

Yoder, C. O. (1995). Policy issues and management applications for biocriteria. In W. S. Davis \& T. P. Simon (Eds.), Biological assessment and criteria: Tools for water resource planning and decision making (pp. 1519). Boca Raton, FL: CRC Pr.

Zamora-Munoz, C., \& Alba-Tercedor, J. (1996). Bioassessment of organically polluted Spanish rivers, using biotic index and multivariate methods. Journal of the North American Benthological Society, 15, 332-352. doi:10.2307/1467281.

Zarger, T. G., Scanion, D. H., Nicholson, C. P., Brown, S. R., Starnes, L. B., \& Harned, W. D. (1986). Ecological recovery after reclamation of toxic spoils left by coal surface mining. Phase II. An assessment of environmental changes following intensive remedial treatments. Tennessee Valley Authority, Report TVA/ONRED/LSER/86/59. 